This item was submitted to Loughborough's Research Repository by the author.

Items in Figshare are protected by copyright, with all rights reserved, unless otherwise indicated.

\title{
Rights, risks and responsibilities in the recruitment of children within the global football industry
}

PLEASE CITE THE PUBLISHED VERSION

https://doi.org/10.1163/15718182-02704005

\section{PUBLISHER}

Brill Academic Publishers

VERSION

AM (Accepted Manuscript)

\section{PUBLISHER STATEMENT}

This paper was accepted for publication in the journal The International Journal of Children's Rights and the definitive published version is available at https://doi.org/10.1163/15718182-02704005.

LICENCE

CC BY-NC-ND 4.0

\section{REPOSITORY RECORD}

Mason, Carolynne, Paul Darby, Eleanor Drywood, James Esson, and Serhat Yilmaz. 2019. "Rights, Risks and Responsibilities in the Recruitment of Children Within the Global Football Industry". Loughborough University. https://hdl.handle.net/2134/9989009.v1. 


\title{
Rights, risks, and responsibilities in the recruitment of children within the global football industry
}

*Carolynne Mason- School of Sport, Exercise and Health Sciences, Loughborough University, UK

Paul Darby - School of Sport, Ulster University, UK

Eleanor Drywood- School of Law and Social Justice, University of Liverpool, UK James Esson- School of Social Sciences and Humanities, Loughborough University, UK

Serhat Yilmaz- School of Sport, Exercise and Health Sciences, Loughborough University, UK

*corresponding author

\begin{abstract}
This paper examines children's engagement with the increasingly global and commercialised football industry. By combining a Global Production Network approach and the United Nations Convention on the Rights of the Child it is argued that, for children's rights and best interests to be better upheld and realised within the football industry, regulatory conditions need to account for geographical contextuality and incorporate scope for children to inform regulatory frameworks and practice. The paper highlights the importance of designing and implementing research that recognises and operationalises children's agency, which can both inform and influence regulations and practices, to better reflect children's best interests.
\end{abstract}

\section{Key words}

Children in sport, Children's Rights; Agency; Football; Soccer 


\section{Introduction}

Football is routinely described as a global industry (Giulianotti and Robinson, 2009). Beyond the growth and scale of the commercial revenues that it generates, the sociocultural reach and appeal of the game around the world, aided by media broadcasting, positions it as one of the most significant global cultural practices of our time. Children have long been trained for, and contracted to, work in the football industry (Pitchford et al. 2004). But the intensification of football's economic and cultural impact has resulted in the demand for, and recruitment of, talented labour becoming increasingly transnational, liberalised, competitive, speculative and oriented around children (Campbell, 2011; Akindes, 2013; Meneses, 2013; Agergaard and Tiesler, 2014). These changes have been accompanied by heightened concerns around the welfare and rights of children within football despite increased regulations which aim to protect them (Donnelly and Petherick, 2004; Brackenridge et al. 2006; Darby et al. 2007).

Academic research and recent media revelations have documented how engagement with the football industry can expose children to emotional and physical harm, sexual abuse, financial exploitation and human trafficking, and in so doing contravene or impinge their rights as enshrined in the United Nations Convention on the Rights of the Child (UNCRC) (Lembo, 2011; Esson, 2015a; Stafford et al. 2015; Elliasson, 2017; Yilmaz et al. 2018). The realisation that encounters between children and the football industry remain far from unproblematic has given rise to an ongoing debate involving international, regional and national governing bodies of the game, sport and non-sport NGOs, politicians, the media and the United Nations around how best to ensure that the 
interests and well-being of young football players are adequately protected and risks to their rights and welfare are identified and addressed (Donnelly and Petherick, 2004; Lindberg, 2006; European Commission, 2007).

This article intervenes in this debate by arguing that for children's rights to be protected and realized within the football industry, the regulatory instruments that govern their journeys need to recognize geographical contextuality and incorporate scope for children to inform regulatory development and practice. In building this argument we firstly conceive of the development of young talent for the professional football industry as occurring within global production networks (GPNs) (Darby, 2013). The GPN framework enables the experiences of children within football to be drawn out in ways that illustrate their connectedness to a range of actors and highlights the impact of those actors upon children's experiences within the complex world of football recruitment. We then draw on the United Nations Convention on the Rights of the Child (UNCRC) as a framework for understanding the broad scope of children's rights and as a tool for auditing the football industry's GPNs in order to identify potential sites of rightsviolation.

By drawing on both the GPN framework and the UNCRC we are able examine tensions that currently exist between football's recruitment practices and the realization of children's rights. Whilst acknowledging that children's journeys through football's GPN provide opportunities for the realization of their rights we demonstrate that these journeys also potentially expose them to a range of rights violation risks. Through auditing this social phenomenon utilising both the GPN and the UNCRC frameworks, this article 
connects to wider debates in the field of childhood studies particularly around tensions that exist between children's agency and the need to protect children within a global context (Miljeteig, 1999).

We begin the article by outlining children's engagement with recruitment processes within the football industry as occurring within GPN nodes. We then explore four sites of interaction between these nodes and children's rights using UNCRC articles and principles which are particularly pertinent to recruitment practices in football: the right to be protected from economic exploitation (i); the right to be protected from violence, abuse, maltreatment and exploitation (ii); rights to survival and development, education, health and family life (iii) and the need to balance the child's best interests with their right to have their voice heard (iv). We conclude the article by highlighting the importance of designing and implementing research that both recognizes and operationalizes children's agency in order to inform and influence regulatory frameworks and practices.

\section{Children's engagement and recruitment in the global football industry}

At the turn of the $21^{\text {st }}$ century it was suggested that 'almost half the 40 articles dealing directly with children's rights are occasionally or routinely violated when we consider children's involvement...with sports' (Donnelly and Petherick 2004; 301). However, the interactions between children's rights and football recruitment processes are relatively underexplored (Drywood, 2016). This is despite significant numbers of children around the world being enmeshed in a wide range of networks, engaging with a variety of key 
actors and stakeholders and experiencing an assortment of mechanisms that may lead to their entry as contracted workers in the global football labour market (Darby et al. 2018).

In unpacking these networks and understanding where child rights violations in football potentially occur, we build on previous work that examined the development of young talent as occurring within global production networks (GPNs) (Darby, 2013). GPNs, defined as 'the nexus of interconnected functions and operations through which goods and services are produced, distributed and consumed', (Henderson et al., 2002) allow us to contend that the trajectory of children who progress from informal, localized versions of the game to its professional ranks takes them through six key nodes. These nodes are represented in Figure 1 below.

\section{Figure 1. Football's Global Production Network}

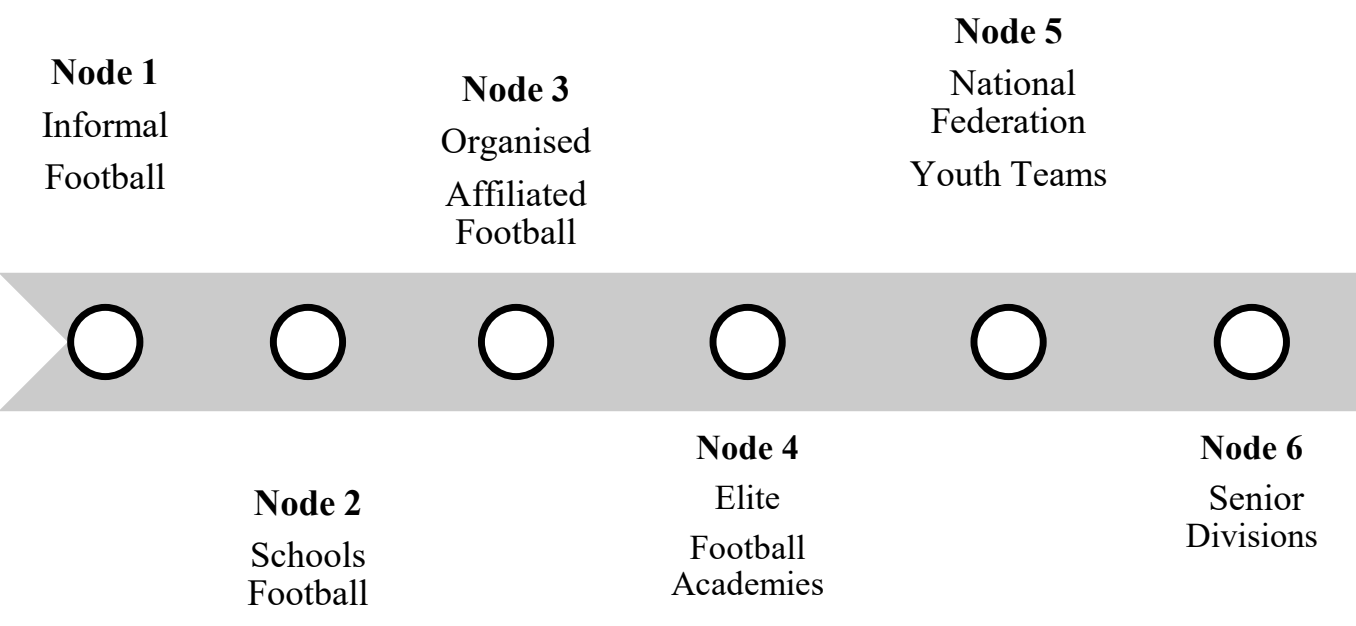

Early exposure to informal football (Node 1) represents the common entry point for children's engagement with football. This occurs at an early age, involves informal play with peers, siblings or parents in a variety of settings, and is linked to the pervasiveness 
of football around the world and the opportunities it offers for physical activity and enjoyment. It is also still the case that schools (Node 2) provide an important entry point into sport and physical activity for children (Hardman, 2008) despite geographical variance in the status of Physical Education (PE) in education systems around the world. The popularity of football globally is such that this sport features prominently in both PE curricula and in inter-school competition around the world. These incipient sites of interaction sit outside the more formalized, structured elements of football (Node 3), yet they are crucial in determining the flow of young players into the game's GPNs (Darby, 2013; Poli, 2005a). The actors that children encounter here such as teachers, coaches, and family mentors, play a crucial role in influencing early experiences and motivations to pursue a professional career in the game. Some actors will have relationships with clubs or intermediaries that facilitate identified children's entry into those nodes that are explicitly oriented around producing professional players and it is these children that are the focus of this paper.

Node 3 runs alongside elite youth football structures which are characterized by a more performance-oriented environment focused on producing professional players. There is permeability here with young players being channelled towards, and recruited into, these structures through their engagement with amateur youth football. The increased global dominance of football is demonstrated by recent developments in countries where football has traditionally not featured in education systems including South Korea, China and Japan (cf. Light, 2007; Duerden, 2012; Lee, 2015). 
Football academies (Node 4), defined as facilities or programmes that aim to identify, develop and often export talent for the professional game, are a critical node in football GPNs (Darby et al. 2007) as it was recently revealed that $55 \%$ of under- 18 players with a professional contract had entered the professional game through an academy (FIFPro, 2016). There is considerable variance, internationally, in how football academies are structured and operate and how they engage young players. All have a primary focus on football training, but many also require children to attend school, either on-site or in local schools. Some are entirely residential and involve players living at the academy facility away from the parental home. Others will be non-residential and young players will continue to live at home while making frequent visits to the academy facility to train and play matches. Some academies require players to train on a part-time or time limited basis while others are full-time and year-round.

Most professional European football clubs have their own academy. The minimum age at which clubs can recruit varies across different national contexts but in England for example, where the minimum age is nine, many clubs operate affiliated development programmes which cater for younger players. Thus, in practice, the reach of professional clubs often extends to children of any age. The further players progress through the academy system, the more intensive the demands and commitment becomes. Beyond facilitating the recruitment and development of domestic talent, there are myriad academies that operate more transnationally and produce talent in one national context with the aim of exporting it to another. These academies are particularly prominent throughout Africa and Latin America (Darby et al. 2007; Poli and Besson, 2011; Trumper and Wong, 2011; Rial, 2014). Alongside the more organised segments of the 
academy system in Africa and Latin America, there are a range of improvised, nonaffiliated set-ups run by local entrepreneurs that seek to produce players for the domestic and international market (Melero and Sorion, 2012; Robalinho, 2013; Lindholm, 2016).

Football academies are also increasingly prominent as part of the Chinese government's drive to turn the country into a football superpower by 2050. For example, in 2012 Guangzhou Evergrande, China’s most successful club, opened a \$185 million football academy in rural southern China catering for 2,400 boarding students (Beech, 2014). A $\$ 9$ million facility based in Hainan also opened its doors to 1000 children from ages 6 and upwards in 2017 (Phillips, 2017). The growth in youth football academies as part of state aspirations to build footballing prowess has also been prominent in Qatar where the multisport Aspire Academy has a strong emphasis on football. The Doha based football program has been operating since 2004 and caters for Qatari youth aged between 12-18. However, it also operates transnationally through its 'Aspire Football Dreams' (AFD) project which since 2007 has recruited 20 players each year, mainly from Africa, most of whom are placed at Aspire's sister facility in Senegal (Abbot, 2018). Academies are pivotal in the training of young players for a career as a professional footballer. Nevertheless, it is important to note that the development of young players is augmented by national football federations (Node 5), some of whom operate national football centres of excellence oriented around training players for national youth teams and ultimately for senior national squads.

From the perspective of clubs, producing a talented player who graduates from its youth academy into the first team is a cheap, albeit labour intensive, method of filling player 
rosters which can potentially save millions of dollars on transfer fees. Identifying and monitoring young players as potential recruits is another common approach employed by clubs to build their squads in a cost-efficient manner and many clubs tend to operate in some of the lesser developed football regions in order to minimize labour costs and potentially maximize 'sell-on' values. However, it should also be noted that academy training does not automatically produce a finished player capable of sustaining a professional career. In the majority of cases players do not fulfil their ambitions, even those trained at the best equipped academies with direct channels to international football markets. Most young players are released during their academy training or do not progress through particular milestones and receive scant support to deal with the emotional and material difficulties that result (Weedon, 2014; Calvin, 2017; Van der Meij et al. 2017).

From this review of children's recruitment into football's GPNs, a number of key themes emerge: the pervasive nature of football in the lives of children, via both formal and informal structures; the complex web of actors (parents, coaches, intermediaries) who facilitate, or hinder, children's football journeys; the cultural and economic capital of football - as an investment for emerging superpowers, as a route out of poverty for children and their families, and the continual search for assets by clubs; and, finally, the precarity of journeys through football's GPNs for many children.

Whilst the GPN is useful in describing children's journeys it tends to prioritize the voracious appetite of the football industry as its frame of reference. Regulatory frameworks exist in order to protect children within football recruitment practices but the 
effectiveness of these in realizing a broad spectrum of children's rights have been questioned (Yilmaz et al. 2018). In order to redress this the UNCRC is utilized here to audit recruitment practices within the football industry's GPN.

\section{A child-rights audit of recruitment practices within football's GPN}

The UNCRC defines a 'child' as every human being under the age of 18 years (Article 1) and recognizes rights held by children in key areas of their lives. The UNCRC was selected for the current analysis ${ }^{1}$ because it enumerates wide-ranging and globally accepted standards of children's rights and most crucially it recognizes children as subjects and holders of human rights. Underpinning these rights are four cross-cutting principles which are to be applied when making decisions that affect children, or when elaborating laws and policies which impact upon them. These are: that primary consideration must be given to the best interests of the child in all actions affecting them (Article 3(1); that the child has a right to participation in all matters affecting them, in accordance with their age and maturity (Article 12); that the child has a right to survival and development (Article 6), and; that the child has a right to non-discrimination (Article

1 'This, of course, does not mean that the UNCRC has not attracted criticism over the years for, inter alia: its western-centric nature; its focus upon rights and not duties; its (alleged) encroachment upon parental rights; its (apparent) incompatibility with feminism; its treatment of children as (allegedly over-) rational beings. See Priscilla Alderson, 'Common Criticisms of Children's Rights and 25 Years of the IJCR' (2017) International Journal of Children's Rights 25 (2) 307-319 for a summary of these critiques. 
2). We acknowledge that an audit based on the UNCRC should be sensitive to the cultural context in which children grow up and should demonstrate an understanding of why actors behave as they do within this environment (Shrestha and Giron, 2006).

In the discussion that follows we use the UNCRC to audit potential children's rights violations arising from the nodes most closely aligned to recruitment specifically for the football industry outlined in our GPN summary above these being academies, youth and adult teams. The discussion focuses on four key sites of interaction between football's global recruitment practices and the potential violation of children's rights namely: the right to be protected from economic exploitation (i); the right to be protected from violence, abuse, maltreatment and exploitation (ii); rights to survival and development, education, health and family life (iii) and the need to balance the child's best interests with their right to have their voice heard (iv).

\subsection{Children's right to be protected from economic exploitation}

At the heart of the operation of football's GPNs are questions around economic exploitation of children. Article 32 of the UNCRC recognizes the right of the child to be protected from economic exploitation and from performing any work that is likely to be hazardous, to interfere with the child's education, or to be harmful to the child's health or physical, mental, spiritual, moral or social development. The most sinister football recruitment practices will be addressed further below, but even the mere practice of paying children to play football raises questions around the compatibility of child labour with Article 32 UNCRC. Beyond the basic requirement to protect children from economic exploitation, the UNCRC goes on to require that state parties may set a 
minimum age for admission to employment (Article 32(1)). Legally, professional footballers are recognized as employed workers so fall within labour legislation, but in many jurisdictions' exceptions to limitations on children's work are found where the employment is for the purposes of cultural and sporting activities, or where there is a vocational element. This means that in many parts of the world an academy scholarship falls outside the protection of any ban on the employment of children, because it falls within the sporting arena and contains educational elements.

There are many aspects of football's global production network that are inconsistent with Article 32 of the UNCRC. Academy players become club 'assets' from the age of 9 (or even younger), with investment in training and education justified based on the commercial gain they may bring to the club in the future, at a level and intensity which is linked to the sporting potential shown by the individual child. A good example of this is training compensation that is paid to clubs that train young players which makes them valuable assets for clubs within a global marketplace for players. However, because of FIFA's classification system for academies, training compensation is minimal for clubs or academies in Africa and to a lesser extent South America, and transfer fees are often negotiated to try to maximize returns (Meneses, 2013; Palmiéri, 2015; Esson, 2016). Moreover, football in Argentina, Brazil, Chile, Colombia, Ecuador, Mexico and Peru is increasingly populated by individuals seeking to buy the commercial rights of talented players as young as nine years old (Meneses, 2013). This situation is not unique to Latin America, and similar activities have been observed in West Africa where 'card dealers' and 'managers' engage in financial speculation by purchasing player registration cards from club owners and moving them to a club they have an affiliation with. A player 
cannot be forced into moving, but they are usually happy to do so as they receive financial gifts as part of a deal (Esson, 2016).

\subsection{Children's right to be protected from violence, abuse, maltreatment and exploitation}

Article 19 of the UNCRC requires that children are protected from all forms of physical or mental violence, injury or abuse, neglect or negligent treatment, maltreatment or exploitation, including sexual abuse. The Convention also places an obligation on states parties to ensure that appropriate protections are in place against all forms of exploitation (Articles 34 and 36). Crucially, the UNCRC framework highlights that this violence can be carried out by a range of individuals who have children in their care (see, for example, Article 19(1)). Brackenridge (2010) has highlighted the range of violence and abuse that child footballers can be subject to, including: discrimination and harassment based on sex, race or sexual orientation; various forms of sexual violence; physical maltreatment; emotional and psychological abuse; neglect; and, child labour and trafficking. Whilst these sorts of abuses can occur regardless of the context surrounding the participation in sport, the practices in football's GPN described above illustrate how precarious circumstances can exacerbate risk factors. Where the pressure to succeed is particularly acute, and for those who have left their home and family to succeed in the football industry, the vulnerability to abusive adults is especially high.

Evidence of the vulnerability of children to abusive adults within the football industry is apparent in two forms of football related human trafficking, known as trafficking through and in football (Poli 2010b; Esson 2015a;). Trafficking through football relates to the 
criminal activities of individuals, posing as football scouts or agents, who use football and the prospect of trials overseas to fraudulently extract money from the parents of eager young players. This process invariably ends with the player being taken to Europe, usually on a short-term visitor visa, and abandoned often without attending a trial. While problematic, there is some debate whether this meets the legal definition of human trafficking (Esson and Drywood, 2018). Trafficking in football involves a similar route to Europe and in some more recent cases to South and East Asia, but trials do materialize, and professional contracts are secured. However, what allows this process to be defined as trafficking is that these contracts are often highly exploitative and unfavourable for the player with agents taking as much as $50 \%$ of the player salary for the duration of the contract (see also David, 2004).

Child trafficking as part of football's GPN results from the states' (collective) failure to prevent the operation of cross-border illicit networks and this blatant failure to uphold Article 35 UNCRC is a direct result of the inadequacy of national, bilateral and multinational measures to prevent the sale of, or traffic in children, for any purpose or form. Intra-state bodies such as the EU are in a particularly powerful position to intervene with more effective policy solutions, something which they have legal competences to do (Drywood, 2016). The effectiveness of these agencies would undoubtedly benefit from greater policy coherence and collaborative working with football authorities (Lindsey and Darby, 2018). Policy makers in football are largely powerless in responding to trafficking through football which is a criminal matter requiring an appropriate response from national crime and border control agencies in the countries where players are trafficked 
from. Anti-trafficking measures notoriously fall-foul of a number of regulatory weaknesses, such as poor levels of victim identification and weaknesses in cross-border law enforcement cooperation, requiring carefully tailored responses which are grounded in the local context(s) in which trafficking occurs (Blazek et al. 2018).

Responsibility for preventing trafficking in football and indeed, ameliorating the other risks to children as a result of engaging in the GPN lie squarely at the feet of the football authorities at international, regional and national levels. In this respect, the Fédération Internationale de Football Association (FIFA) adopted measures, under the Regulations on Status and Transfer of Players (RSTP) in 2001, to govern children's international movement in football with a view to protecting them. In particular, Article 19 of the RSTP allows the cross-border mobility of children in football in only certain exceptions and under the scrutiny and approval of FIFA and national associations. By following a strict interpretation of the rule, FIFA recently santioned several high profile clubs in European football due to regulatory infringements related to the transfer of minors under the RSTP (Yilmaz, 2018).

FIFA's Regulations on Working with Intermediaries (RWI) (2015) also incorporate a remuneration prohibition for agents in the representation of players under the age of 18 . This rule also intends to prevent the exploitation of minors by curtailing their mobility, but also their potential representation, by disincentivising agents in the process (Yilmaz et al. 2018). However, European wide rules that aim to help nurture 'home-grown' talent by restricting the number of foreign players, and inconsistent national policies on the 
minimum age at which players can sign professional contracts, have inadvertently made the global football industry a precarious environment for young migrant players (Heidman, 2013; Rowe, 2016). FIFA's deregulation of the agent market via the RWI likely exacerbated this issue further. Therefore, the recent decision by FIFA to re-regulate agents (FIFA 2018) is certainly an important development with regards to the protection of children in their engagement within football's GPN.

\subsection{Children's rights to health, education and family life}

The journey through football's global production networks for children can throw up challenges to the realization of rights in relation to education, healthcare and family life. Provisions of the UNCRC focus on the right of children to retain contact with their parents (Article 9) and to family reunification where they are separated (usually in migration scenarios) (Article 10), underlining the importance of the family unit to children. The Convention's preamble states: [the family is] the fundamental group of society and the natural environment for the growth and well-being of all its members and particularly children. Whilst it is not uncommon for children to live away from their families, but within their country of residence, risks to the enjoyment of family life are particularly acute where children migrate as part of football's GPN.

The importance of the family unit in potentially providing a nurturing environment for children is undeniable yet it is also important to acknowledge that family members often play a significant role in a child's decision to pursue a football career and may support their attempts to progress through the football industry's GPN both financially and emotionally. While this point is valid in many parts of the world, it has significant 
implications in Africa, Latin America and other developing contexts where, as discussed above, formal and/or well-paid employment opportunities are scarce and/or precarious. In such contexts, the pursuit of a career in football is often encouraged by family members as part of a broader household livelihood strategy (see Meneses, 2013; Palmiéri, 2015; Van der Meij and Darby, 2017). The outcome is additional pressure on children to succeed in an already competitive and pressurized environment. Relatedly, an emerging issue concerning the impact of football on children's rights to education in Latin American and sub Saharan African countries are cases of children from low income families dropping out of school to pursue a career in football (Esson, 2013; Meneses, 2013).

David (2004) has also identified restrictions on education due to involvement in sport as a key situation which can threaten physical and mental integrity of children and their enjoyment of rights. Whilst football can be a positive factor in the education of children, the pressure and time demands of elite sport can be disruptive to a child's schooling. Article 28 of the UNCRC, as well as recognizing the right to education, emphasizes the importance of availability, accessibility and regular attendance. Football's governing bodies require detailed education plans for academy players and individuals with responsibility for education are in place at clubs with a youth structure. In the UK, for example, it is also standard practice for academies to be subject to the same inspections as publicly funded schools. However, whilst education provision is of a high standard at the most elite levels of the game, the precarious situation facing children pursuing a career in football through the less formal structures of the global production network is likely to result in much more disruption to education. Children who have been involved 
in football related migration and find themselves with an irregular immigration status are unlikely to access consistent and appropriate education.

Like education, there are many attendant benefits to children's health through participation in football; equally, however, David (2004) has highlighted that the highpressured environment of sport can threaten the physical health of children. The UNCRC grants all children the right to the best possible health, including an obligation to offer education on health and well-being (Article 24). Threats from within football can include doping, overtraining, concussion, amongst others. Children who are under pressure to succeed, fuelled by the demands of footballs GPN, are most at risk of submitting to practices that may be harmful to them because of a drive to succeed in a competitive industry.

The final section in our audit of children's rights in football examines the UNCRC's underpinning principle of best interests and outlines how this broad value can be used to weigh up the potential harms and benefits to the rights of children as they come into contact with football's GPNs.

\subsection{The best interests of the child}

There are significant ways in which the regulation of football's recruitment processes does not operate in the best interests of the child (as recognized in Article 3(1) UNCRC), primarily because the sporting and commercial interests at play shape their implementation in practice. A series of regulatory frameworks around the transfer system, designed to ensure a free-flowing and liberal market in footballers and the availability of talent, have the (normally unintended) consequence of operating against 
the best interests of the children involved. This is the case in relation to, for example, training compensation which incentivizes clubs to acquire players at as young an age as possible to minimize their future economic liability. A similar effect is caused by the homegrown player rule. Whilst this provision was introduced with a view to offering greater opportunities to young, local players, its operation within the context of global supply networks in football has resulted in clubs prioritizing securing the services of very young players so that they can be converted to homegrown players by the time they become 18 .

Where regulatory systems are designed without considering the impact on children at the stage of design and formulation, unintended consequences with an injurious impact upon the rights of children are likely to follow. It is, therefore, important that football's governing bodies engage with a children's rights ethos. FIFA has begun to move in this direction through its FIFA Guardians - Child Safeguarding Toolkit (FIFA 2019) which is designed to protect children in football. This initiative is directly underpinned by a recognition of the need for the football industry to act in the best interest of children and to respect and promote children's rights as enshrined within the UNCRC. The International Federation of Professional Footballers (FIFPro) has also been an important advocate for better protection of children and for recognition of their rights in football's GPN. Under the auspices of the World Players Association (WPA), FIFPro has been involved in the adoption of the Declaration on Safeguarding the Rights of Child Athletes (WPA 2017) setting out key principles and action areas for stakeholders to work together to ensure that sport is a safe place for children. 
Without this child rights approach, the myriad rights violations associated with football's GPNs outlined above may continue. However, casting young footballers as passive victims of rights violations is also problematic (Esson and Drywood, 2018). Young players very often claim to exercise rational agency in their decision to pursue a career in football and the journey through football's GPNs (and its associated harms and benefits) is a calculated risk that they accept.

Research has pointed to the degree of agency which young academy players in Ghana, for example, display when choosing to migrate for football purposes, a decision which is taken on the rational basis of future opportunities (Darby et al. 2018). Where a football club with the infrastructure to train and educate a footballer offers this opportunity, it is perhaps understandable that a player and their family see no reason why they should not to pursue it seriously. Indeed, this need to balance a child's welfare (that is, to take decisions in their best interests) with their autonomy (that is, their right to have their views given due weight) is enshrined in the UNCRC (Article 12). The tension at the heart of the UNCRC between the need to protect children from harm and their autonomy as individuals who possess agency is very much encapsulated by the complex mix of rightsopportunities and rights-violations offered by a journey through football's GPN. Given the precarity of children's journey through the game what constitutes the 'best interests of the child' in the longer term may be very difficult to ascertain at the point at which young players and their families make these decisions. 


\section{Conclusion}

Children who participate in football with an aspiration to become a professional player navigate a fragmented and risk-laden system where there is considerable variation within, and between, countries in terms of the protection offered to children's rights. At best, football recruitment practices result in a range of rights (health, education and economic) being realized for children (and their families) that otherwise would not be available. This paper has identified and examined 'sites' of interaction between the global football industry's recruitment network and risks to the rights of the child as enumerated in the United Nations Convention on the Rights of the Child (UNCRC). Utilising the GPN to document children's journeys and the UNCRC as an auditing tool has enabled individual and contextual perspectives of children's experiences to be articulated and tensions between the football industry's recruitment practices and the realisation of children's rights to be revealed.

An important finding is that upholding the rights of children to be protected from economic exploitation and from performing any work that is likely to be hazardous, to interfere with the child's education, or to be harmful to the child's health or physical, mental, spiritual, moral or social development (Article 32 UNCRC) will remain a challenge for football (and other commercialized sports) given increasingly profit driven practices. The risks that have been articulated within this paper exist in part because football's regulatory structures do not recognize children's agency and the relevance of geographical context and therefore actors and regulatory structures within football's GPNs do not necessarily operate in the best interests of the child. 
The paper's wider contribution to scholarship lies in highlighting risks of potential childrights violations within football recruitment and in stimulating a debate on the methodological and conceptual approaches that may be used to continue the analysis of children's engagement with professional sport. Significantly this paper has made evident the need to ensure that children's experiences are understood firstly within the broader context of their childhood development and secondly with recognition of the full range of actors who impact on their journeys and the varied motivations of these actors. It has also highlighted that what is currently lacking in these debates is empirical data that examines engagement in, and experiences of football's GPN, by placing the individual child at the heart of research design and implementation. Such research is needed if regulations and policies are to work in the best interests of the children they are supposed to protect. 


\section{References}

Abbot, S. The Away Game: The Epic Search for Football's Next Superstars (Edinburgh: Arena Sports, 2018).

Agergaard, S., \& Tiesler, N. C., (eds.) Women, Soccer and Transnational Migration (London: Routledge, 2014).

Akindes, G. A., "South Asia and South-East Asia: New Paths of African Footballer Migration”, Soccer \& Society 2013 (14 (5)), 684-701. DOI: 10.1080/14660970.2013.792486.

Beazley, H., Bessell, S., Ennew, J., \& Waterson, R., “The Right to be Properly Researched: Research with Children in a Messy, Real World”, Children's Geographies 2009 (7 (4)), 365-378. DOI: $10.1080 / 14733280903234428$.

Beech, H., "Welcome to China's Everghrande, the World's Biggest Soccer Academy”, TIME June 2014.

Blazek, M., Esson, J., \& Smith, D. P., "Relational Geographies of Human Trafficking: Inequality, Manoeuvring and Im/mobility Across Space and Time”, Transactions of the Institute of British Geographers 2018 (44), 63-78. DOI: 10.1111/tran.12271.

Brackenridge, C., \& Rhind, D., "Child Protection in Sport: Reflections on Thirty Years of Science and Activism”, Social Sciences 2014 (3 (3)), 326-340. DOI: 10.3390/socsci3030326.

Brackenridge, C., "Children's Rights in Football: Welfare and Work", Proceedings of the International Conference on Centres and Peripheries in Sport, the Department of Sport Sciences, 
Malmo University, Sweden, 8-12 April 2010. Available at;

http://bura.brunel.ac.uk/handle/2438/4240

Brackenridge, C., Pitchford, A., Russell, K., \& Nutt, G., Child Welfare in Football: An

Exploration of Children's Welfare in the Modern Game. (London: Routledge, 2006).

Bourdillon, M. F., Rights and Wrongs of Children's Work. (New Brunswick, New York and London: Rutgers University Press, 2010).

Calvin, M., No Hunger in Paradise: The Players, The Journey, The Dream. (Century; London, 2017)

Campbell, R., "Staging Globalization for National Projects: Global Sport Markets and Elite Athletic Transnational Labour in Qatar", International Review for the Sociology of Sport 2011, (46(1)) 45-60. DOI: 10.1177/1012690210368887

Darby, P., Akindes, G., \& Kirwin, M., "Football Academies and the Migration of African Football Labour to Europe", Journal of Sport and Social Issues 2007 (31(2)), 143-161. DOI: $10.1177 / 0193723507300481$

Darby, P., "Moving Players, Traversing Perspectives: Global Value Chains, Production Networks and Ghanaian Football Labour Migration.”, Geoforum 2013 (50), 43 - 53. DOI: 10.1016/j.geoforum.2013.06.009

Darby, P, Esson, J, Ungruhe, C., "Migration, Sport for Development and Sports Academies: The Case of Football in Africa." In Collison, H., Darnell, S., Giulianotti, R. and Howe, P.D. (eds) Routledge Handbook of Sport for Development and Peace, (London; Routledge, 2018). 
David, P., Human Rights in Youth Sport: A Critical Review of Children's Rights in Competitive Sport. (London; Routledge, 2004).

Drywood, E. W., “' ‘When we buy a young boy...': Migrant Footballers, Children's Rights and the Case for EU Intervention.” In I. Iusmen, \& H. Stalford (eds.), The EU as a Children's Rights Actor (Opladen, Berlin \& Toronto; Barbara Budrich, 2016)

Duerden, J., "South Korean Teams Fight for Attention at Home”, New York Times, 2012, 9 October. https://goal.blogs.nytimes.com/2012/10/09/south-korean-soccer-teams-fight-forattention-at-home/? _php=true\& type=blogs\&_r=0.

Donnelly, P., \& Petherick, L., "Workers' Playtime? Child Labour at the Extremes of the Sporting Spectrum.”, Sport in Society, 2004 (7(3)), 301-321. DOI: 10.1080/1743043042000291659.

Eliasson, I., “The Gap Between Formalised Children's Rights and Children's Real Lives in Sport.”, International Review for the Sociology of Sport, 2017 (52(4)), 470-496. DOI: $10.1177 / 1012690215608516$.

Esson, J., “A Body and a Dream at a Vital Conjuncture: Ghanaian Youth, Uncertainty and the Allure of Football.”, Geoforum, 2013, (47), 84-92. DOI: 10.1016/j.geoforum.2013.03.011.

Esson, J., "Better Off At Home? Rethinking Responses to Trafficked West African Footballers in Europe.”, Journal of Ethnic and Migration Studies, 2015a (41(3), 512-530. DOI: 10.1080/1369183X.2014.927733. 
Esson, J., "You Have to Try Your Luck: Male Ghanaian Youth and the Uncertainty of Football Migration.”, Environment and Planning 2015b, 47(6), 1383-1397. DOI:

10.1177/0308518X15594920.

Esson, J., "Football as a Vehicle for Development: Lessons from Male Ghanaian Youth in Ansell.” N., Klocker, N. and Skelton, T. (eds.). Geographies of Global Issues: Change and Threat. (Berlin; Springer Singapore, 2016).

Esson, J., \& Drywood, E., "Challenging Popular Representations of Child Trafficking in Football.”, Journal of Criminological Research, Policy and Practice, 2018 4(1), 60-72 Online.

European Commission (2007) "White Paper on Sport". Available at: http://ec.europa.eu/sport/documents/wp on sport_en.pdf.

Fédération Internationale de Football Association, Regulations on Working with Intermediaries, 2015. Available at: https://resources.fifa.com/image/upload/regulations-on-working-withintermediaries-2367763.pdf?cloudid=cr6dquxm2adupv8q3ply.

Fédération Internationale de Football Association, Football Stakeholders endorse landmark reforms of the transfer system, 2018. Available at: https://www.fifa.com/governance/news/y=2018/m=9/news=football-stakeholders-endorselandmark-reforms-of-the-transfer-system.html.

Fédération Internationale de Football Association, FIFA Guardians Child Safeguarding Tookit for Member Associations, 2019. Available at: https://resources.fifa.com/image/upload/toolkitfifa-guardians.pdf?cloudid=nz1lyz3ykaioy $7 \mathrm{gwfmgs}$. 
The FA, The FA National Game: The State of the Game Report, London, 2015. Available at: file:///C:/Users/bscljm1/Downloads/9386-fa-state-of-the-game-final-apr15.pdf

Giulianotti, R., \& Robertson, R., Globalization and Football. (London: Sage, 2009).

Hardman, K., "Physical Education in Schools: A Global Perspective", Kinesiology 2008 (40(1)), 5-28. DOI: 10.2478/v10038-008-0001-z

Heidmann, M., Transferts et Formation des Jeunes Footballeurs en Europe: du" Rêve Sportif" à la Régulation Politique: Une Socio-Ethnographie Politique au Coeur des Institutions Européennes. PhD thesis. Université de Strasbourg, 2013.

Henderson, J., Dicken, P., Hess, M., Coe, N., \& Yeung, H. W. C., “Global Production Networks and the Analysis of Economic Development.", Review of International Political Economy, 2002, (9(3)), 436-464. DOI: 10.1080/09692290210150842.

Huijsmans, R., "Children Working Beyond Their Localities: Lao Children Working in Thailand.”, Childhood, 2008, (15(3), 331-353. DOI: 10.1177/0907568208091667.

Kilkelly, U., “Operationalising Children's Rights: Lessons from Research.”, Journal of Children's Services, 2006, (1(4)), 35-46. DOI: 10.1108/17466660200600030.

Lee, J. W., "Football and Migration: An Analysis of South Korean Football”, in R. Elliot and J. Harris (eds.) Football and Migration: Perspectives, Places, Players. (London; Routledge, 2016). 
Lembo, C., "FIFA Transfers Regulations and UEFA Player Eligibility Rules: Major Changes in European Football and the Negative Effect on Minors.”, Emory International Law Review, 2011 (25), 539-585.

Light R., "Globalisation and Youth Football in Japan., Asian Journal of Sport and Exercise, 2007, (4(1)), 21-27.

Lindberg, K.,"The Man Who Traced 442 Soccer Slaves.”, Play the Game 2006. Available at: http://playthegame.org/upload/Magazine\%202005/themanwhotraced442slaves.pdf

Lindholm, J., "Can I Please Have a Slice of Ronaldo? The Legality of FIFA's Ban on ThirdParty Ownership Under European Union Law.”, The International Sports Law Journal 2016 (15(3-4), 137-148. DOI: 10.1007/s40318-015-0075-7.

Lindsey, I., \& Darby, P., "Sport and the Sustainable Development Goals: Where is the policy coherence?”, International Review for the Sociology of Sport 2018. DOI: 1012690217752651.

Melero, V., \& Sorion, R., “The Dilemma of Third-Party Ownership of Football Players.”, EPFL Sports Law Bulletin, 2012, (10), 41-44.

Meneses, J. P., Niños Futbolistas. (Barcelona: Blackie Books 2013).

Miljeteig, P., "Introduction: Understanding Child Labour.”, Childhood 1999 (6(1)), 5-12. DOI: $10.1177 / 0907568299006001001$.

Palmiéri, J. C. J. "Um mundo em vários movimentos: uma etnografia sobre futebolistas de base." $\mathrm{PhD}$ thesis. Available 
at:https://repositorio.ufscar.br/bitstream/handle/ufscar/7291/TeseJCJP.pdf?sequence=1\&isAllow

$\underline{\mathrm{ed}=\mathrm{y}}$

Pitchford, A., Brackenridge, C., Bringer, J. D., Cockburn, C., Nutt, G., Pawlaczek, Z., \& Russell, K., "Children in Football: Seen but not heard.", Soccer \& Society 2004 (5(1)), 43-60. DOI:

$10.1080 / 14660970512331390994$.

Phillips, T. "China aims for football glory with academy based on Barcelona's"', Guardian, 6 March 2017.

Poli, R., “The Football Player's Trade as Global Commodity Chain. Transnational Networks from Africa to Europe. Université de Neuchâtel 2005a. Available at: https://doc.rero.ch/record/7825/files/Poli_Raffaele -

The football player s trade 20070524.pdf

Poli, R., “Agents and Intermediaries” in Chadwick S (ed.) Managing Football: An International Perspective. (Oxford: Butterworth Heinemann, 2010a).

Poli, R., "The Migrations of African Football Players to Europe: Human Trafficking and Neocolonialism in question.” Paper presented at Football for Development. Vienna, Austria 2010b. Available at: http://www.footballfordevelopment.net/uploads/tx_drblob/storage/Poli_migrationof-African-football-players_01.pdf

Poli, R, and Besson, R., "From the South to Europe: A Comparative Analysis of African and Latin American Football Migration”, in Falcous, M, and Maguire, J. (eds.) Sport and Migration: Borders, Boundaries and Crossings. (London; Routledge 2011). 
Rial, C., "Circulation, Bubbles, Returns: the Mobility of Brazillians in the Football System", in R. Elliot and J. Harris (eds.) Football and Migration: Perspectives, Places, Players. (London; Routledge 2014).

Robalinho, M., Third-Party Ownership of Football Players: Why are the Big Actors in the Football Market Afraid? (Booktango.2013).

Rowe, M., “The Beautiful Game?”, Geographical, 2016 (88 (11)), 33-39.

Shrestha, B. and Giron, G., "Regional Capacity Building Workshop on Monitoring and Evaluation Tools and Mechanisms", Save the Children 2006. Available at: https://resourcecentre.savethechildren.net/sites/default/files/documents/1761.pdf

Stafford, A., Alexander, K., \& Fry, D., “There Was Something That Wasn't Right Because That Was The Only Place I Ever Got Treated Like That': Children and Young People's Experiences of Emotional Harm in Sport.”, Childhood 2015 (22(1)), 121-137. DOI: $10.1177 / 0907568213505625$.

Trumper, R and Wong, L. L., “Transnational Athletes: Celebrities and Migrant Players in Fútbol and Hockey", in Falcous, M, and Maguire, J. (eds.) Sport and Migration: Borders, Boundaries and Crossings (London: Routledge 2011).

Van der Meij, N and Darby, P., "Getting in the game and getting on the move: Family, the intergenerational contract and football academies in Ghana.”, Sport in Society 2017 (20(11)), 15801595. DOI: 10.1080/17430437.2017.1284807. 
Webbink, E., Smits, J., \& de Jong, E., "Hidden Child Labour: Determinants of Housework and Family Business Work of Children in 16 Developing Countries.” World Development 2012 (40(3)), 631-642. DOI: 10.1016/j.worlddev.2011.07.005.

Weedon, G., "Youth Migration in English Professional Football: Living, Labouring and Learning in Premier League Academies", in R. Elliot and J. Harris (eds.) Football and Migration: Perspectives, Places, Players (London: Routledge 2014).

White, B., "Defining the Intolerable: Child Work, Global Standards and Cultural Relativism.", Childhood 1999 (6(1)), 133-144. DOI: 10.1177/0907568299006001010.

World Players Association Declaration on Safeguarding the Rights of Child Athletes, 2017. Available at: https://www.uniglobalunion.org/news/world-players-association-launches$\underline{\text { declaration-protect-child-athletes }}$

Yilmaz, S., "Protection of minors: Lessons about the FIFA RSTP from the recent Spanish cases at the Court of Arbitration for Sport?", The International Sports Law Journal, 2018 (18(15)), 1528. DOI: $10.1007 / \mathrm{s} 40318-018-0126-\mathrm{y}$

Yilmaz, S., Esson, J., Darby, P., Drywood, E., \& Mason, C., "Children's Rights and the Regulations on the Transfer of Young Players in Football”, International Review for the Sociology of Sport 2018 Online. DOI: 1012690218786665. 